\title{
CEOS.F

\section{INFORMATION MANAGEMENT AND EXPONENCIAL LEARNING IN SOCIETY 5.0: FOUNDATIONS FOR AN INTEGRATED SYSTEM}

\author{
Dalbert Marques Oliveira ${ }^{1}$, Patrícia Miranda Pereira ${ }^{1}$ \\ ${ }^{1}$ Institututo Superior de Contabilidade e Administração do Porto (PORTUGAL)
}

\begin{abstract}
Individuals use information to reduce discomfort, effort and errors. Thinking about it, headphones were invented, so that the music could be heard without disturbing others; household appliances, to reduce the effort in washing dishes or clothes; and calculating machines, so that human distraction would not cause an accident in calculating the weight that a bridge could bear. But the information has hardly changed the certainties and doubts about which is the most suitable college course to attend; what are the best practices that could contribute to the individual's daily life, during the academic career, which includes when and what to study, what to eat and what to do in their free time. It is undeniable that there is greater access to information, but many times, instead of browsing this information, the individual sinks into it. In addition, teachers and students remain stuck in curriculum, with the same menu being provided for carnivores, vegetarians or lactose intolerants. If before students were beaten with rules in their hands and were attacked psychologically, having to learn the same as everyone else, nowadays only rules have ceased to exist, at least in theory. Reducing errors in choosing a higher education course and the entire life that governs the academic path can be a dream for many individuals and an integrative system that collects information about the individual and guides him in his academic path could be an extremely useful compass. Know which college course to take; knowing which discipline, among the electives, to choose; know the right time to get up and sleep; what to do throughout the day; what and when to eat; they are all informational outputs that the utopian system could provide, in order to contribute to the individual's success. This paper will attempt to discuss these issues, investigating part of the enabling technologies in today's Society 5.0. The objective is to initiate a debate on the delegation to an integrative system of data, information and knowledge management, the success of individuals and society.
\end{abstract}

Keywords: education data meaning, integrated system, know thyself, machine learning for education, Society 5.0 .

\section{INTRODUCTION}

Information, combined with technology, has contributed to improving the quality of life of individuals and the whole society. It is through working with information that we acquire knowledge and it is the practice of knowledge that leads us to wisdom. We are adept at using this wisdom to reduce discomfort, effort and errors (cf. Bledow et al., 2017; Froehlich, 2017). There are numerous tools and technologies that have emerged for this purpose, among these tools are electronics and home appliances (Doering \& Carmo, 2020).

But when the goal is self-knowledge, despite the "Delphic maxims" known since ancient Greece: "know thyself" (Tubbs, 2016) and all the efforts in the area of medicine, psychology and other sciences, it seems that we have only scratched the surface of our possibilities. A search through the Google Play Store (Google, 2020a) or the Apple Store (Apple, 2020), is able to recover numerous applications that intend to help individuals acquire self-knowledge (Barreau, 1995), several of these systems only collect data and provide indicators in isolation (cf. Dong, 2005); moreover, some individuals may not be prepared to analyze the information that these systems provide and apply them in their daily lives. These systems are also separated by areas such as sport (cf. Strava, 2020), food 
(cf. MyFitnessPal, 2020) and finance (cf. Intuit Mint, 2020), making it even more complex to manage this information (cf. Razmerita, Kirchner \& Sudzina, 2009).

In education, it is no different. There are several systems that aim to guide individuals about education, teaching (cf. Coursera, 2020; Pereira, Pedrosa \& Bernardino, 2015), concentration (cf. Headspace, 2020), but these systems hit the barrier of the individual himself and subjectivity (Saunders et al., 2015). In turn, the educational system is built to promote the equality of individuals, where everyone is obliged to learn, in the same way, the same disciplines in order to obtain a specific diploma (cf. Decreto-Lei no 74/2006 do Diário da República, 2006; cf. Decreto-Lei no 369/2007 do Ministério da Ciência, Tecnologia e Ensino Superior, 2007; cf. Lei no 38/2007 da Assembleia da República, 2007; cf. Lei no 38/1994 da Assembleia da República, 1994; Pereira, Araújo \& MachadoTaylor, 2015). They preach equality rather than equity. They forget or are not able to treat each individual with their own unique needs.

However, it appears that these difficulties are lessening. In Japan, at the beginning of 2016, the concept of Society 5.0 emerged, which aims to enhance the work of technology, information and knowledge, for the benefit of the individual and society (Fukuyama, 2018). In the midst of this new society, exponential and disruptive technologies are the hope for the practice of equity and for individual and social self-knowledge.

This paper analyzes some technologies that seek to enhance individual self-knowledge. It performs this analysis in search of an integrated system that enhances this self-knowledge, focusing on individual education (cf. Uline, 1996).

\section{2 "KNOW YOURSELF"}

The importance of self-knowledge as an important action for human beings, was already considered in ancient Greece, being known, among other names, as the "Delphic maxims" (Tubbs, 2016). Knowing who you are, the flavors and the unpleasantness, the dispositions and the indispositions, the pretensions and the indifference, can contribute to the personal or social success or failure (Swann \& Read, 1981). Wisdom is related to the practice of knowledge (Cooper, 2017) and to know it is necessary to acquire and manage information (cf. Barreau, 1995). This acquisition can be made through channels, such as the senses or the intellect, through the collection of data in a conscious or even unconscious way (Classen, 1999).

The importance of information for the production of knowledge and as an enabler of personal and social success, is observed in the so-called Information Society, Knowledge Society and more recently Society 5.0 (Fukuyama, 2018) that makes use of its predecessors.

Among the utilities of information is the reduction of discomfort, effort and errors (cf. Bledow et al., 2017; Froehlich, 2017). In an illustrative way, it is possible to mention that with the information technologies were created: that made it possible to reduce the discomfort that others might feel, when a certain individual is listening to a song (headphones); sweat less when washing clothes (washing machine); avoid accidents, in the calculations necessary for the construction of a bridge (calculating machines).

Still regarding the reduction of errors, the correct information, applied to self-knowledge, enables the reduction of errors that individuals may make in various areas of their life (Senders \& Moray, 2020). The educational area is expected to be one of them (Ashford \& Cummings, 1983). The correct information could collaborate to choose the ideal higher education course for each individual, for the study routine, for the correct food for educational success, for the discovery of hobbies that provide intellectual development, for the choice of recreational activities that contribute academic training, to understand and use the individual's entire circadian cycle in favor of a healthy life, which contributes to learning (cf. Archer \& Oster, 2015; Coo et al., 2019; Ríos Flórez, López Gutiérrez \& Escudero Corrales, 2019).

\subsection{The concern with education}

It is possible to find in the literature, works that demonstrate that the concern with what to learn and how to learn, begins before university life. Among these works is one of Wiig (1997), who mentions the need to understand which concepts and meta-knowledge that individuals, at an early age, need to learn in order to become capable adults in their countries. More recently, there is an area of data mining that is concerned exclusively with enhancing education (Mohamad \& Tasir, 2013). 
However, once enrolled in a higher education course, the individual becomes a "hostage" of the curriculum (course plan), being obliged to take all mandatory subjects to obtain the diploma. In many higher education courses, perhaps the majority of which are Western Higher Education Institutions (HEls), the same mandatory subjects are taught to all individuals, in the same way, in search of a fanciful equality. There are laws and regulations that surround the curriculum of these courses (Pereira, Araújo \& Machado-Taylor, 2015). These laws and regulations, many of them relatively recent, as is the case with the accreditation processes for undergraduate degrees in Portugal (cf. Decreto-Lei no 74/2006 do Diário da República, 2006; cf. Decreto-Lei ํo 369/2007 do Ministério da Ciência, Tecnologia e Ensino Superior, 2007; cf. Lei no 38/2007 da Assembleia da República, 2007; cf. Lei no 38/1994 da Assembleia da República, 1994) try to make the courses train individuals in what companies need. However, individuals are different, have different educational and social backgrounds and only one equity would serve this diversity (Kaur, 2012).

That said, in the review carried out for this study, HEls that apply equity in their curricula or teaching methods were not found. In Portugal, educational institutions that apply such equity are very rare. This research found a basic school, called Escola da Ponte, which promotes teaching adapted to the differences and characteristics of individuals. These individuals organize themselves according to the needs of their training, through reflections, developing their capacities for critical analysis and research (Pacheco \& Pacheco, 2015; Silva \& Ribeiro, 2018).

The other institutions, in search of equality in the midst of differences, psychologically attack individuals, who, for not being able to learn at the same speed as their "equals", even abandon the course (cf. Brito et al., 2014; Lehmann, 2007). There is a certain similarity with the physical aggressions that teachers used to spend on their pupils in the past (Oladiran, 2012). The difference is that the old aggressions could leave physical marks, superficially visible, on the other hand, the current curricular grades, leave deep psychological marks.

There is an urgent need for a change in higher education, but it is also urgent to equip individuals with tools that allow them to know themselves. We do not refer to vocational tests that show, in a static and momentary way, the individual's propensity to become a doctor or engineer (Faria, 2020; Farsen, Fiorini \& Bardagi, 2017; Singh et al., 2020); but rather, a technology that accompanies the individual throughout his life, that collects, analyzes and learns his habits, his routines, his flavors and his discomfort, his dispositions and his indispositions, his pretensions and their indifference, and provide guidance to the individual. These guidelines could cover areas such as: information about higher education would be the most suitable; which discipline, among the electives, to choose; knowing the right time to get up, according to the circadian cycle; what to do throughout the day; what and when to eat. These are informational outputs that the utopian integrated system could provide, in order to contribute to the individual's success, including guidance on the best study routine, the correct diet, hobbies and recreational activities that can contribute to their academic training, among others. other possibilities.

\section{SOCIETY 5.0 AND THE POSSIBILITIES}

Society 5.0 is a concept created by Japan in the Fifth Science and Technology Basic Plan and approved in early 2016 . This society is an information society created based on Society 4.0 in order to create a society that focuses on the human being, so that people have a high quality of life (Fukuyama, 2018).

According to Fukuyama (2018), Society 5.0 intends to meet the needs of human beings. For the author, this society intends to merge the physical world with the digital (cyberspace) to create quality data that will be the basis to start obtaining / building solutions. About this merger Santos and Monteiro (2016) portray a current process, of reciprocal indications, that is, the information is sent to cyberspace, where it is analyzed, and its result will again be sent to the physical world in different formats, where the individual will interpret the results received. There are more and more technologies that use this concept to contribute to the self-knowledge of the individual and society. Among these technologies are exponential and disruptive technologies.

\subsection{Exponential and disruptive technologies}

Exponential technology is based on Artificial Intelligence (Al) and Internet of Things (IoT) to facilitate communication between man and machine and to automate domestic functions with a direct impact on 
safety, and well-being (Doering \& Carmo, 2020). These technologies propose to increase the results, using the same resources or a smaller number of them.

With regard to education, Bolson, Rodrigues and Revello de Lima (2020) comment that these technologies allow not only to broaden the horizons of students within the classroom, instigating their curiosities, but also contribute positively to corporate environments and for the family environment; providing an abundance of information that is available in the most varied media and channels, favoring curiosity, arousing exploration and research, as well as the digital autonomy of these generations (Rolim, Mello \& Costa, 2017; cf. Uline, 1996).

In turn, disruptive technology promotes a process of "revolutionary innovation" with new products and services, with better characteristics, improving social comfort (Serrano \& Baldanza, 2017). As an example of disruptive technologies, which can be used in education, it is possible to mention Web Cookies and recommendation algorithms, including those used by companies such as Netflix and Spotify.

With regard to Web Cookies, these mechanisms - small files capable of storing user data - are used by platforms and online pages to provide targeted advertising related to user behavior. As an example, it is possible to mention its use on social networks: users of social networks provide Web Cookies with information, often unconsciously, regarding their behaviors, which includes among other information, the "friends they like best and with whom more interact, political perspectives, leisure, with whom they have romantic relationships, place of residence, age, nationality, research done, among others "(AuYong-Oliveira et al., 2020, p. 9; cf. Carmi, 2017 ; Kaushik \& Prakash, 2018; Koop, Tews \& Katzenbeisser, 2020). This information is used to present these users with products and services that may be of interest to these individuals.

In turn, Netflix, an online platform that provides audiovisual content for a monthly fee (Subscription Video On Demand), uses recommendation algorithms based on the autonomous collection of data from previous activities and behaviors of its own users (Gomez- Uribe \& Hunt, 2015). In this way the platform creates recommendations using the RMSE (Root Mean Square Error) system in which high quality recommendation algorithms are used, reducing the RMSE to the maximum. RMSE makes use of meta tags and the user's own behavior on this platform, which includes the tastes left in videos and shares on social networks (Sigiliano \& Faustino, 2016).

What Web Cookies and algorithms like those of the RMSE system do, is the creation of user profiles (cf. Barati et al., 2020) useful to recognize the individual and insert him in categories, in order to improve the marketing of products and services for these individuals.

Another technology that can be applied to education is machine learning (ML) which aims to help machines and computers learn to make the best decisions from data, previously inserted or retrieved (Nafea, 2018; Praveena \& Jaiganesh, 2018). About ML, Sharma and Kumar (2017) comment: "Through enabling computers to perform specific tasks intelligently, machine learning systems can carry out complex processes by learning from data, rather than following pre-programmed rules" ( $p$. 1548).

$\mathrm{ML}$ applications are also found on social networks that use this learning to maximize the time that the individual spends on these social networks, as well as marketing individualized advertising and creating boots for human interaction (Valtonen et al., 2019). Regarding the application of ML in the educational scope Nafea (2018) comments:

"This kind of assistance helps to enhance students' learning experience and can improve progression and student achievement. Machine learning fosters personalized learning in the context of disseminating education. Advances in Al are enabling teachers to gain a better understanding of how their students are progressing with learning. This enables teachers to create customized curriculum that suits the specific needs of the learners. When employed in the context of education, Al can foster intelligence moderation" (p. 175).

\subsection{Apps that know us}

Other technologies are available in the form of web platforms and applications. Geographically, Google has an application called Maps that is capable of maintaining a history of where the individual was, when he was in that location and the time the individual spent in that location and, through the 
individual's interaction with other applications and users, indicate, for example, places that the individual may like to visit, or even foods that he may like to try (Hsu, Lin \& Ho, 2012). In connection with Google Calendar, it is possible to receive feedback on the time indicated for leaving home, the route and the most suitable means of transport to reach a certain appointment previously entered in the Calendar (cf. Abdalla, 2012; Google, 2020b), which also uses recommendation resources based on the information entered by the user (Wajcman, 2019).

Music platforms are able to indicate new songs to individuals, based on their history and their interaction with the platform, which includes the likes and dislikes that the user provides for a given song (Anderson et al., 2020). Platforms that provide applications such as the Apple Store or the Google Play Store, indicate to the individual applications that may be of interest to him based on his history of use (Rocha, Souto \& El-Khatib, 2020; Saborido et al., 2018). The same process is found on shopping platforms, which indicate products and services to the customer, based on their search history (on or off the platform, using Web Cookies), purchase history and geographic region, among other indicators (Smith \& Linden, 2017).

Applications that promise to positively collaborate with the individual's mood, such as Daylio (Daylio, 2020), Cíngulo (Cíngulo, 2020) and Question Diary (Google, 2020c), use the information entered by users to present graphics and recommendations that intend to equip the individual with tools for the feeling of well-being.

Platforms for personal organization, such as Evernote (Evernote, 2020), make it easy to manage tasks and appointments. The Todoist (Doist, 2020) that goes further, realizing where the individual is and informing him about the activities that must be carried out in that place. There are applications for various areas, such as Organizze (Organizze, 2020) for financial management and HabitBull (HabitBull, 2014), which allows to check people's habits and routines.

But all of these systems require a workload on the part of individuals, who have to enter data into the systems and analyze and apply the information that these systems provide. Few systems have an active and autonomous data collection, in a smaller number are those that communicate with other applications and other areas of the individual's life to collect, analyze and provide indicators for individuals. Furthermore, these systems delegate to the individual a good part of the application of information in his personal life (cf. Barreau, 1995; Dong, 2005; Razmerita, Kirchner \& Sudzina, 2009).

However, those who have already gained weight because they ate, unconsciously, in the wrong way; that missed the date of an appointment because he relied on memory; and failed in a project because he trusted intuition or self-assessment of indicators, he knows that there are individuals who may have difficulties in maintaining, on their own, a routine of conscious use of these systems, not being able to trust themselves to achieve full self-knowledge.

\section{AN INTEGRATED SYSTEM FOR EDUCATIONAL SELF-KNOWLEDGE}

Returning to the "Delphic maxims", it invites each one of us to know ourselves (Tubbs, 2016). It is hoped that the individual will be able to know what he is made, and from there find the most suitable material to improve in a wise way. But given the subjectivity of this assessment (Saunders et al. 2015), mistakes, deception or even forgetfulness are common, and the individual is not able to achieve full knowledge of himself.

As mentioned, we have technologies, at our fingertips, that guide us about our food education, with the possibility of specialist monitoring (MyFitnessPal, 2020); we have online files with information about our schedules, contacts, directions (Microsoft, 2020); we can keep a virtual diary of events and feelings, with indexed information that allows us to recover a certain day and see how we claim to feel at that moment (Cíngulo, 2020). And we have several online vocational tests that promise to affirm our propensities in education and work (Faria, 2020; Saunders et al., 2015), for example the Myers-Briggs Type Indicator (MBTI) (The Myers-Briggs Company, 2020) and My Next Move (National Center for O*NET Development, 2020).

But these vocational tests are subjective, because we, who do them, or the professionals who apply them, are individuals and therefore subjective (Saunders et al., 2015). The test does not reach that book that we can come to read and totally modify our life goals, the test does not perceive the nuances of our restlessness during sleep which can modify our mental abilities the next day; he doesn't know that we had a family fight the night before and that this fight made us dislike a certain area that was previously considered our passion and that maybe it can become again. 
What this paper proposes is an integrated system that can bring together all the technologies and systems mentioned here, including WEB Cookies, ML and algorithms such as RMSE, to get to know us better. This integrated system would retrieve information from our entire life, autonomously, analyse this information and provide us with outputs in an effective and efficient way, for our day-today lives, in order to achieve individual success, contributing to the success of all the society.

Briefly, we will comment on some areas and requirements that this integrated system should cover to achieve the proposed objectives.

\subsection{Offline and online life}

Increasingly, some individuals maintain a busy life online. It is in cyberspace, or using the technologies derived from it, that individuals study, work, interact and have fun (cf. Marshall, 2014). But these same individuals continue to use the physical world to satisfy their physiological needs such as sleeping, eating and exercising, often using cyberspace technologies, such as the aforementioned applications, to support these activities.

And why not bring all these technologies together in one? All the information that is retrieved by the various platforms and programs, mentioned above, and still others, could be worked with the use of $\mathrm{ML}$, to be able to better understand the individual and provide him with valuable outputs about his daily life, about what to study and what experiences to have, in order to be able to exercise the professional functions that you want, functions that could also be guided by this integrative system.

An integrative system that reaches both environments (online and offline) must always be close to the individual and gather information about the world around him in several ways. He must analyse the user's life, both online and offline. You should also correlate these aspects with the professions as well as with the disciplines that prepare the user to perform the functions related to these professions (Pereira, Araújo \& Machado-Taylor, 2015).

Offline it is necessary to collect physiological information from the individual, which includes the properties about what the individual consumes and excretes, how these properties affect his heart rate and blood pressure, his sleep cycles and waking; information about people's habits and routines; regular and sporadic activities; places you visit, length of stay in these places; their habits of reading, studying, working, sports, leisure and hobbies.

Online, it is necessary to collect information about the applications, platforms, web sites you use, why, how, where and when you use them. This includes user interactions with these online channels, which must count the research you do, the comments you write, the reactions you provide; with whom, why, how, where, when and how often they interact; the content of the messages you send and receive, through all communication channels such as e-mails, chats, SMS.

In addition, it is necessary to compare these data and information with a set of existing and potential courses and study plans, which must correlate with the existing and potential functions and professions.

\section{CONCLUSIONS}

Know thyself implies being able to predict a series of parameters about yourself, among these parameters, the behaviors towards certain situations. In this paper we analyze the enabling power of information to know the individual and how this knowledge is used by applications to provide products and services to its users.

We analysed the emerging technologies of society 5.0, and how they work with information focused on the individual. We have also seen that although there are several systems that aim to improve the quality of life of individuals, these systems require a workload and depend on the individuals themselves to function. This dependence is problematic given the subjectivity and inconsistency of individuals, as well as the "human error" factor. In addition, these systems work in an unrelated way, increasing the need for attention on the part of the individual in having to seek information in different systems to know himself.

We therefore propose an autonomous and independent system, which integrates several other systems for the collection of data, the analysis of these data, and the provision of individualized information to the individual, in a format, place and opportune time, in an effective and efficient way, 
which will provide the material individual for his self-knowledge and consequently for him to achieve success for himself and for society as a whole.

However, given popular expressions such as "learn by making mistakes" (Shallenberger, 2015) and the common sense that error teaches more than success, the question opens up about the possibility of reducing mistakes, turn out to be detrimental to the development of the individual. Are errors really necessary for development? (cf. Bledow et al., 2017; Castro \& Tedesco, 2020; Fazekas et al., 2020; Souza, Schubert-Backes \& Delacanal-Lazzari, 2017).

Another pertinent issue, but which was not addressed by this work, is related to issues of ethics and information privacy. Even if the individual provides all the authorizations to have his life analyzed by the system, there are laws that prevent certain information, even if released by the individual, from being analyzed for the creation of profiles (Barati et al., 2020). And how to analyze the information derived from the individual's interaction with his peers, without hurting ethics and data protection laws?

All of these issues must be investigated so that a utopian integrative system is part of the daily lives of future human beings.

\section{REFERENCES}

Abdalla, A. (2012). Latyourlife: a geo-temporal task planning application. In Gartner G., Ortag F. (Eds.), Advances in Location-Based Services (pp. 305-325). Springer. https://doi.org/10.1007/9783-642-24198-7 20

Anderson, A., Maystre, L., Mehrotra, R., Anderson, I., \& Lalmas, M. (2020). Algorithmic Effects on the Diversity of Consumption on Spotify. In Y. Huang, I. King, T. Liu \& M. van Steen (Eds.), WWW'20: Proceedings of The Web Conference 2020 (pp. 21552165). Association for Computing Machinery. https://doi.org/10.1145/3366423.3380281

Ashford, S. J., \& Cummings, L. L. (1983). Feedback as an individual resource: Personal strategies of creating information.
In Organizational behavior and human performance, (Vol.
32 ,
pp.
370-398).

Elsevier. https://doi.org/10.1016/0030-5073(83)90156-3

Apple. (2020). Apple Store. https://www.apple.com/app-store/

Archer, S. N., \& Oster, H. (2015). How sleep and wakefulness influence circadian rhythmicity: effects of insufficient and mistimed sleep on the animal and human transcriptome. In D. Dijk (Ed.), Journal of Sleep Research, $\quad$ (Vol. $\quad 24, \quad$ pp. 493). Wiley Blackwell. https://doi.org/10.1111/jsr.12307

Au-Yong-Oliveira, M., Sousa, A., Silva, E., Lin, F., \& Ferreira, I. (2020). Instagram, Facebook e YouTube: quem é mais eficaz na sua publicidade? Revista Ibérica De Sistemas e Tecnologias De Informação, 34, 1-12.

Barati, M., Rana, O., Petri, I., \& Theodorakopoulos, G. (2020). GDPR Compliance Verification in Internet of Things. In D. Abbott, IEEE Access (Vol. 8, pp. 119697-119709). IEEE. https://doi.org/10.1109/ACCESS.2020.3005509

Barreau, D. K. (1995). Context as a Factor in Personal Information Management Systems. In J. Mostafa (Ed.), Journal of the American Society for Information Science (Vol. 46, pp. 327-339). Wiley. https://doi.org/10.1002/(SICl)1097-4571(199506)46:5<327::AID-ASI4>3.0.CO;2-C
Bledow,
R., Carette,
B., Kühnel,
J.,
\& Bister,

D. (2017). Learning From Others' Failures: The Effectiveness of Failure Stories for Managerial Learnin g. In W. M. Foster (Ed.), Academy of Management Learning \& Education, (Vol. 16, pp. 3953). https://doi.org/10.5465/amle.2014.0169

Bolson, J. B., Rodrigues, K., \& Revello de Lima, M. R. (2020). O conhecimento para o mundo exponencial: As metodologias ativas na prática pedagógica. SCIAS - Educação, Comunicação e Tecnologia, 2(1), 6-22. https://doi.org/10.36704/sciaseducomtec.v2i1.4345

Brito, D. M., Almeida Júnior, I. A., Queiroga, E. V., \& Rêgo, T. G. (2014). Predição de desempenho de alunos do primeiro período baseado nas notas de ingresso utilizando métodos de aprendizagem de máquina. 25ำ Simpósio Brasileiro de Informática na Educação [Symposium] (pp. 882890). https://doi.org/10.5753/cbie.sbie.2014.882

Carmi, E. (2017). Regulating behaviours on the European Union internet, the case of spam versus cookies. In International Review of Law, Computers \& Technology, (Vol. 32, pp. 289-307). https://doi.org/10.1080/13600869.2017.1304616

Castro, F., \& Tedesco, P. (2020). Promovendo a Reflexão sobre o Erro em Disciplinas Introdutórias de Programação no Ensino Superior. Revista Brasileira de Informática na Educação, 28, 150165. https://doi.org/10.5753/rbie.2020.28.0.150 
Cíngulo. (2020). Cíngulo. https://www.cingulo.com/

Classen, C. (1999). Other Ways to Wisdom: Learning Through the Senses Across Cultures. In D. Atchoarena, S. A. Agbor, D. Baril, P. Bélanger, A. Benavot, ..., A. Tuijnman (Eds.), International Review of Education (Vol. 45, pp. 269-280). Springer. https://doi.org/10.1023/A:1003894610869

Coo, I. F., van Oosterhout, W. P. J., Wilbrink, L. A., van Zwet, E. W., Ferrari, M. D., \& Fronczek, R. (2019). Chronobiology and Sleep in Cluster Headache. In T. N. Ward (Ed.), Headache: The Journal of Head and Face Pain, (Vol. 59, pp. 1032-1041). https://doi.org/10.1111/head.13567

Cooper, P. (2017). Data, information, knowledge and wisdom. In N. Pace \& M. Serpell (Eds.), Anaesthesia \& Intensive Care Medicine (Vol. 18, pp. 55-56). https://doi.org/10.1016/i.mpaic.2016.10.006

Coursera. (2020). Coursera. https://www.coursera.org/

Daylio. (2020). Daylio. https://daylio.net/

Decreto-Lei nº 74/2006 do Diário da República (2006). Diário da República: I-A série, n. 60. https://dre.pt/web/guest/legislacao-consolidada/Ilc/122033591/202012051617/exportPdf/normal/1/cacheLevelPage? LegislacaoConsolidada WAR drefrontofficeportlet $\mathrm{rp}=$ indice

Decreto-Lei no 369/2007 do Ministério da Ciência, Tecnologia e Ensino Superior (2007). Diário da República: I série, n.․ 212. https://dre.pt/application/file/a/629341

Doering, T. A. \& Carmo, A. F. C. (2020). Inteligência Artificial e Internet das Coisas aplicada a Automação Residencial. ETIC - Encontro de Iniciação Científica, 16(16).

Doist (2020). Todoist. https://todoist.com/

Dong, X. L. (2005). A Platform for Personal Information Management and Integration. In Proceedings of VLDB 2005 PhD Workshop (pp. 26-30).

Evernote (2020). Evernote. https://evernote.com/int//en/

Faria, C. M. (2020). Orientação Profissional no Contexto Escolar. BIUS-Boletim Informativo Unimotrisaúde em Sociogerontologia, 21(15), 1-14.

Farsen, T. C., Fiorini, M. C., \& Bardagi, M. P. (2017). Análises psicométricas de instrumentos validados em diversos contextos: o caso da escala de adaptabilidade de carreira. Gerais: Revista Interinstitucional de Psicologia, 10(2), 162-175.

Fazekas, J., Jessop, A., Pine, J. \& Rowland, C. (2020). Do children learn from their prediction mistakes? A registered report evaluating error-based theories of language acquisition. In $\mathrm{J}$. Sanders (Ed.), Royal Society Open Science, (Vol. 7). Royal Society. https://doi.org/10.1098/rsos.180877

Froehlich, T. J. (2017). A Not-So Brief Account of Current Information Ethics: The Ethics of Ignorance, Missing Information, Misinformation, Disinformation and Other Forms of Deception or Incompetence. BiD: textos universitaris de biblioteconomia $i$ documentació, (39). https://doi.org/10.1344/BiD2017.39.8

Fukuyama, M. (2018). Society 5.0: Aiming for a New Human-Centered Society. Japan SPOTLIGHT, 47-50.

Gomez-Uribe, C. A., \& Hunt, N. (2015). The Netflix Recommender System: Algorithms, Business Value, and Innovation. ACM Transactions on Management Information Systems, 6(4), 119. https://doi.org/10.1145/2843948

Google. (2020a). Google Play Store. https://play.google.com/store

Google. (2020b). Google Calendar. https://calendar.google.com/calendar

Google

(2020c). Questions Diary: One selfreflection question. https://play.google.com/store/apps/details?id=com.pione.questiondiary\&hl=en US\&gl=US

HabitBull (2014). HabitBull. http://www.habitbull.com/

Headspace. (2020). Headspace. https://www.headspace.com/

Hsu, F. M., Lin, Y. T., \& Ho, T. K. (2012). Design and implementation of na inteligente recommendation system tourist attractions: The integration of EBM model, Bayesian network and Google Maps. B. Lin (Ed.), Expert Systems with Applications, (Vol. 39, pp. 3257-3264). Elsevier. https://doi.org/10.1016/j.eswa.2011.09.013

Intuit Mint. (2020). Mint. https://mint.intuit.com/

Kaur, B. (2012). Equity and social justice in teaching and teacher education. In H. Guðjónsdóttir \& R. Kleinsasser (Co-Ed.) Teaching and Teacher Education, (Vol. 28, pp. 485-492). Elsevier. https://doi.org/10.1016/i.tate.2012.01.012 
Kaushik, G., \& Prakash, R. (2018). Collection of data through cookies and smart devices - A case study. International Journal of Advance Research, Ideas and Innovations in Technology, 4(5), 458461.

Koop, M., Tews, E., \& Katzenbeisser, S. (2020). In-Depth Evaluation of Redirect Tracking and Link Usage. In R. Greenstadt, D. McCoy \& C. Troncoso (Eds.), Proceedings on Privacy Enhancing Technologies, (Vol. 2020, pp. 394-413). https://doi.org/10.2478/popets-2020-0079

Lehmann, W. (2007). "I just didn't feel like I fit in": The role of habitus in university dropout decisions. Canadian Journal of Higher Education, 37(2), 89-110.

Lei no 38/2007 da Assembleia da República (2007). Diário da República: I série, n.ํ 157. https://dre.pt/application/file/a/637086

Lei $\mathrm{n}^{\underline{0}}$ 38/1994 da Assembleia da República (1994). Diário da República: I série, n. 269. https://dre.pt/application/file/a/550772

Marshall, L. (2014). O hiper-infinito. Rizoma, 2(2), 8-17.

Microsoft. (2020). Microsoft 365. https://www.microsoft.com/en-us/microsoft-365/products-appsservices

Mohamad, S. K., \& Tasir, Z. (2013). Educational data mining: A review. In C. S. Teh, \& H. Chae (Eds.), Procedia Social and Behavioral Sciences, $\quad$ (Vol. $\quad 97, \quad$ pp. 320-324). Elsevier. https://doi.org/10.1016/i.sbspro.2013.10.240

MyFitnessPal. (2020). MyFitnessPal. https://www.myfitnesspal.com/

Nafea, I. T. (2018). Machine Learning in Educational Technology. In H. Farhadi (Ed.), Machine Learning-Advanced Techniques and Emerging Applications (pp. 175-183). IntechOpen. https://doi.org/10.5772/intechopen.72906

National Center for O*NET Development (2020). My Next Move. https://www.mynextmove.org/

Oladiran, A. (2012). Disciplining of student's vis-à-vis the duties/responsibilities of vice principals in secondary institutions

Oyo State: Yesterday and today. Educational Research and Reviews, 7(8), 192-195.

Organizze (2020). Organizze. https://www.organizze.com.br/

Pacheco, J. \& Pacheco, M. F. (2015). Escola da Ponte: uma escola pública em debate. Cortez Editora.

Pereira, C. A., Araújo, J. F. F. E., \& Machado-Taylor, M. L. (2015). Acreditação do ensino superior nos países lusófonos: reflexões e práticas em Portugal e Brasil. Conhecimento \& Diversidade, $7(13)$, 28-39.

Pereira, P. J. A., Pedrosa, I. M. M. \& Bernardino, J. (2015). A Escolha de um Curso Superior: Um ranking pessoal. In A. P. Costa, L. P. G. Reis, P. V. L. Cravo, A. C. B. Delbem \& C. J. Coelho (Eds.), Fronteiras: Journal of Social, Technological and Environmental Science, (no. 3, Vol. 4, pp. 64-80). https://doi.org/10.21664/2238-8869.2015v4i3.p64-80

Praveena, M., \& Jaiganesh, V. (2017). A Literature Review on Supervised Machine Learning Algorithms and Boosting Process. International Journal of Computer Applications, 169(8), 32-35. https://doi.org/10.5120/ijca2017914816

Razmerita, L., Kirchner, K., \& Sudzina, F. (2009). Personal knowledge management: The role of Web 2.0 tools for managing knowledge at individual and organisational levels. Online Information Revie w, 33(6), 1021-1039. https://doi.org/10.1108/14684520911010981

Ríos Flórez, J. A., López Gutiérrez, $\quad$ C. R., \& Escudero Corrales, C. (2019). Cronobiología del sueño y su influencia en la función cerebral. Cuadernos de Neuropsicolo gía / Panamerican Journal of Neuropsychology, 13(1), 12-33.

Rocha, T., Souto, E., \& El-Khatib, K. (2020). Functionality based mobile application recommendation system with security and privacy awareness. In E. H. Spafford (Ed.), Computers \& Security (Vol. 97). Elsevier. https://doi.org/10.1016/j.cose.2020.101972

Rolim, V. B., Mello, R. F. L., \& Costa, E. B. (2017). Utilização de Técnicas de Aprendizado de Máquina para Acompanhamento de Fóruns Educacionais. Revista Brasileira de Informática na Educação, 25(3), 112-130. https://doi.org/10.5753/rbie.2017.25.03.112

Saborido, R., Khomh, F., Hindle, A., \& Alba, E. (2018). An app performance optimization advisor for mobile device app marketplaces. In B. Shirazi (Ed.), Sustainable Computing: Informatics and Systems (Vol. 19, pp.29-42). Elsevier. https://doi.org/10.1016/i.suscom.2018.05.008

Santos, M. C. F., \& Monteiro, S. D. (2016). Interfaces como metacomunicação: contribuição da engenharia semiótica na representação no ciberespaço. Informação \& Informação, 21(1), 80102. https://doi.org/10.5433/1981-8920.2016v21n1p80

Saunders, L., Kurbanoglu, S., Boustany, J., Dogan, G., Becker, P., ... \& Todorova, T. (2015). Information behaviors and information literacy skills of LIS students: an international perspe 
ctive. In Journal of Education for Library and Information Science (Vol. 56, pp. 80-99). Association for Library and Information Science Education (ALISE).

Senders, J. W., \& Moray, N. P. (2020). Human error: Cause, prediction, and reduction. CRC Press.

Serrano, P. H. S. M., \& Baldanza, R. F. (2017). Tecnologias disruptivas: o caso do Uber. Revista Pensamento Contemporâneo em Administração, 11(5), 37-48. https://www.redalyc.org/articulo.oa?id=441753779011.

Shallenberger, D. (2015). Learning from Our Mistakes: International Educators Reflect. Frontiers: The Interdisciplinary Journal of Study Abroad, 26(1), 248-263. https://doi.org/10.36366/frontiers.v26i1.369

Sharma, D., \& Kumar, N. (2017). A Review on Machine Learning Algorithms, Tasks and Applications. International Journal of Advanced Research in Computer Engineering \& Technology (IJARCET), 6(10), 1548-1552.

Sigiliano, D., \& Faustino, E. (2016). NETFLIX: Sistemas de Recomendação Inteligentes. Revista Tecer, 9(16), 13-26.

Silva, C. M., \& Ribeiro, C. P. (2018). A apropriação do espaço escolar pelo projeto pedagógico: o caso da Escola da Ponte (Portugal). In Educação e Pesquisa (Vol. 44). https://doi.org/10.1590/s1678-4634201844183443

Singh, S., Srivastav, U., Labroo, R., \& Jain, Y. (2020). UNSCHOOLED.COMEducation for all. Journal of Xi'an University of Architecture \& Technology, 12(4), 3887-3892.

Smith, B., \& Linden, G. (2017). Two decades of recommender systems at Amazon.com. In G. Pallis (Ed.), IEEE Internet Computing (Vol. 21, pp. 12-18). IEEE. https://doi.org/10.1109/MIC.2017.72

Souza, D., Schubert-Backes, V. M., \& Delacanal-Lazzari, D. (2017). Posibilidades en la educación en enfermería: errar, crear y arriesgar. In Enfermería universitaria, (no. 2, Vol. 14, pp. 79-87). ENED. https://doi.org/10.1016/..reu.2017.02.005

Strava. (2020). Strava. https://www.strava.com/

Swann, W. B., \& Read, S. J. (1981). Acquiring self-knowledge: The search for feedback that fits. Journal of Personality and Social Psychology, 41(6), 1119-1128. https://doi.org/10.1037/00223514.41.6.1119

The Myers-Briggs Company (2020). MBTI. https://www.mbtionline.com/en-US

Tubbs, N. (2016). Epistemology as education: Know thyself. In A. Stables, Education Sciences (Vol. 6). https://doi.org/10.3390/educsci6040041

Uline, C. L (1996). Knowledge in the information age: Effortless communication and the effort of reflective thought. In Educational Technology, (no. 5, Vol. 36, pp. 29-32). Educational Technology Publications.

Valtonen, T., Tedre, M., Mäkitalo, K., \& Vartiainen, H. (2019). Media Literacy Education in the Age of Machine Learning. In M. Ranieri \& E. Friesem, Journal of Media Literacy Education (Vol. 11, pp. 20-36). Association for Library and Information Science Education (ALISE). https://doi.org/10.23860/JMLE-2019-11-2-2

Wajcman, J. (2019). The Digital Architecture of Time Management. Science, Technology, \& Human Values, 44(2), 315-337. https://doi.org/10.1177/0162243918795041

Wiig, K. M. (1997). Knowledge management: an introduction and perspective. In Journal of Knowledge Management (no. 1, Vol. 1, pp. 6-14). Emerald Group Publishing Limited. 